\title{
Learning Model "Make a Match" at Class XII IPA (Science) 2 Islamic Education in Senior High School 1 Pasie Raja, South Aceh Regency
}

\author{
Riza Yuliadi \\ Tapaktuan State Islamic Collage \\ rizayuliadi@gmail.com
}

\begin{abstract}
This research deals with Learning Model "Make a Match" at Class XII IPA2 Islamic Education in State Senior High School 1 Pasie Raja, South Aceh Regency. The research conducted was Classroom Action Research (CAR). PTK is one type of action research carried out by education practitioners, especially teachers, lecturers, or instructors in the learning process in the classroom. . Based on the data obtained from the XII class Islamic Education subject teachers, there were 23 students in the XII IPA2 class, consisting of 7 male students and 16 female students. The findings show that there is an increase in student learning outcomes. The actions taken by Islamic Education teachers are Make a Match learning models. The aim is to create learning that is able to attract students' attention, provide knowledge to students to work together with other students in terms of understanding material, able to make students active and enthusiastic in learning. In addition, it can also make students able to reach the KKM graduation limit. The comparison between learning outcomes before taking action and after taking action reached 39.69\%. Where the initial results before taking action are 39\% but after taking action the student learning outcomes reach $78 \%$.
\end{abstract}

Keywords: Learning Models; Make a Match; Islamic Education.

\section{Introduction}

One learning model that can overcome the problem of low student learning outcomes is to use the Make a Match learning model. Make a Match learning model or finding a partner is one alternative that can be applied to students. The application of this model starts with techniques, namely students are told to look for pairs of cards which are answers or questions given by the teacher before the lesson begins, students are expected to be able to find the pairs of cards before the specified time limit, students who can match cards faster will be given points. Through this Make a Match learning model, besides being able to actively improve student learning outcomes, creative can also develop the values of the ability to participate effectively between one student and another, and accompanied by a sense of togetherness and responsibility. By applying the Make a Match learning model or finding a partner this will make students more active in the teaching and learning process.

Make a Match learning model or looking for a partner has several advantages including being able to create an active and pleasant learning atmosphere, the learning material delivered attracts students 'attention, able to increase students' absorption of learning material and make the lesson more meaningful for students, the atmosphere of excitement will grow in the learning process, collaboration between fellow students is realized dynamically, the emergence of a dynamic of mutual cooperation that is evenly distributed across all students. This is a learning plan through the Make a Match learning model that I do so that students every lesson they receive will be more meaningful to them. 


\section{Theoretical Framework}

\subsection{Learning Models}

The learning model is the pattern used in planning learning in class and tutorial. The learning model is basically a form of learning that is illustrated from the beginning to the end which is presented specifically by the teacher. In other words, the learning model is a wrapper or frame from the application of an approach, method, and learning technique. The learning model is a pattern or plan carried out by the teacher when teaching in class so that students are more enthusiastic in the learning process, and when a teacher wants to apply a learning model or method first, the ways or steps must be taken so that the learning process runs smoothly as desired.

As for Soekamto, et al., The purpose of the learning model is: "a conceptual framework that describes a systematic procedure in organizing learning experiences to achieve certain learning goals and serves as a guide for learning designers and instructors in planning teaching and learning activities." Thus learning activities really is a systematic aiming activity.

\subsection{Definition of Make a Match Learning Model}

Make a Match learning model or finding a partner is one type of method in cooperative learning. The application of this model starts with techniques, namely students are told to look for pairs of cards which are answers / questions before the deadline, students who can match the cards are given points.

This learning model is very interesting if we apply because it is important in interacting between one student and another student, will motivate students to respond to what is given by the teacher, and also with this model students will be more active and enthusiastic in the teaching and learning process, helping students build own knowledge and help students process their own information because where this model will bring more students in demand to think a lot to find answers or questions they read and will be able to solve problems within themselves. This will require students to be more active and become learning independent so that you get maximum learning outcomes.

\subsection{Learning Outcomes}

Learning outcomes consist of two words, namely results and learning, results are something held by the business, According to Djamarah, results are the achievements of an activity that has been done, created. Results will never be obtained as long as people don't do something. To get results it takes struggle, sacrifice, tenacity, sincerity, strong will.

Learning is an intentional activity carried out by individuals so that there is a change in self-ability, by learning that children who have been unable to do something or children who were previously unskilled became skilled.

Gagne in his book The Conditions of Learning reveals that learning is a kind of change that is shown in behavior change, the situation is different from before the individual is in a learning situation and after taking similar actions. Changes occur due to an experience or practice. In the matter of learning, Gagne gives two definitions.

a. Learning is a process to gain motivation in knowledge, skills, habits, and behavior.

b. Learning is knowledge or skills obtained from instruction. 


\section{Research Method}

The research conducted was Classroom Action Research (CAR). PTK is one type of action research carried out by education practitioners, especially teachers, lecturers, or instructors in the learning process in the classroom.

The results of the research data presented by the researcher are observational data and recordings of activities from the implementation of the actions that took place in Pasie Raja 1 High School South Aceh District.

In accordance with the time determined by the researcher and Ms. Lili Marhani as the eye teacher of the Islamic Religious Education Study, a meeting was held to discuss how the class conditions would be the subject of the research, namely class XII IPA2. Based on the data obtained from the XII class Islamic Education subject teachers, there were 23 students in the XII IPA2 class, consisting of 7 male students and 16 female students.

This Classroom Action Research is conducted in two Cycle I cycles, and Cycle II. Cycle I on January 5, 2017, and the second cycle on January 12, 2017 Data analysis per cycle.

\section{Discussions}

\section{a. Pre Cycle}

The preliminary data that researchers consider to be the initial guideline for conducting research is to use the results of the daily (formative) test. The data will then be used as a starting point before action is taken. This research began with observation and interviews with XII grade teachers. Based on interviews and observations, the problems that occur in the class include teachers who have not used learning media optimally and have not used varied media. This causes students to be less enthusiastic in the learning process and tend to be passive students in the learning process. The above causes student PAI learning outcomes to be less than optimal. Based on the results of observations, it is necessary to take an action to overcome the above problems. The initial data before the action are as follows:

Table 4.1 List of Pre Cycle Values

\begin{tabular}{|l|l|l|c|c|}
\hline No & Name & Value & Complete & Uncompleted \\
\hline 1 & Andi Erizal & 70 & $\checkmark$ & \\
\hline 2 & Ernawati & 65 & & $\checkmark$ \\
\hline 3 & Ghanda Arsenda & 75 & $\checkmark$ & \\
\hline 4 & Husna Wahyuni & 70 & $\checkmark$ & \\
\hline 5 & Ilham Amrin & 70 & $\checkmark$ & \\
\hline 6 & Isra Mianda & 50 & & $\checkmark$ \\
\hline 7 & Lisma Ismail & 70 & $\checkmark$ & \\
\hline 8 & Marhaban & 50 & & $\checkmark$ \\
\hline 9 & Mirna Lisa & 70 & $\checkmark$ & $\checkmark$ \\
\hline 10 & Nelva Amiriza & 65 & & $\checkmark$ \\
\hline 11 & Nova Rosita & 60 & & \\
\hline 12 & Nurgantisyah & 72 & $\checkmark$ & \\
\hline
\end{tabular}




\begin{tabular}{|c|l|l|c|c|}
13 & Nurjanah & 40 & & $\checkmark$ \\
\hline 14 & Nyak Baren & 50 & & $\checkmark$ \\
\hline 15 & Rahmawati & 80 & $\checkmark$ & \\
\hline 16 & Riski Juanda & 50 & & $\checkmark$ \\
\hline 17 & Riski Safriana & 40 & & $\checkmark$ \\
\hline 18 & Salmianti & 45 & & $\checkmark$ \\
\hline 19 & Ulva Ardianti & 60 & & $\checkmark$ \\
\hline 20 & Ulvia Rahmayanti & 50 & & $\checkmark$ \\
\hline 21 & Wawan Setiawan & 75 & $\checkmark$ & \\
\hline 22 & Yolanda & 55 & & $\checkmark$ \\
\hline 23 & Zulfikar & 65 & & 14 \\
\hline & total & 1392 & 9 & 60.86 \\
\hline & Average & 60.52 & 39.13 & \\
\hline
\end{tabular}

Data Source: Documentation of SMAN 1 Pasie Raja, 2016.

Based on the table above, it can be seen that of the 23 students who took the pre-test in the pre-cycle as many as 9 students who had achieved the minimum completeness criteria (KKM), while 14 other students still had not achieved the specified completeness. By looking at the results of the data above it is necessary to have corrective actions in learning through learning media, namely media images so that student learning outcomes are expected to increase. For more details, see the table below.

Table 4.2 Student learning outcomes Pre Cycle

\begin{tabular}{|l|c|}
\hline Criteria & Pre Cycle \\
\hline Average student learning outcomes & $60.52 \%$ \\
\hline Student learning completeness & $39.13 \%$ \\
\hline
\end{tabular}

Data Source: Data on student learning outcomes, 2017

Diagram 4.1 Pre Cycle Learning Result Chart

\begin{tabular}{|c|c|}
\hline & Pre Cycle Student Learning Outcomes \\
$80.00 \%$ & $60.52 \%$ \\
$60.00 \%$ & average student \\
$40.00 \%$ & $\begin{array}{l}\text { completeness of } \\
\text { learning average } \\
\text { student learning }\end{array}$ \\
\hline $0.00 \%$ & learning outcon \\
\hline
\end{tabular}

Data Source: Data on student learning outcomes, 2017 
In the above results we can see that the pre-cycle that the researcher can say that the results have not reached Minimal completeness criteria $(\mathrm{KKM})^{1}$. Therefore, researchers need to take action by applying the Make a Match learning model to improve student learning outcomes. Researchers hope that by implementing learning Make a Match student learning outcomes will increase.

\section{b. Cycle I}

In accordance with the results of the pre cycle above, the first cycle of action was taken in learning the material Islamic Faith Education to Qada and Qadar in class XII IPA 2 in SMA 1 Pasie Raja in semester 2 of the 2016/2017 academic year using the Make a Match model. This cycle is held on Thursday 5 January 2017.

Implementation This cycle action takes place in four stages, planning, action, observation, and reflection that form one cycle, each of which will be described as follows:

1) Round I Class Action Planning

Before carrying out the action, the researcher prepares action plans that will be carried out by the researcher so that when the action is taken there are no unwanted obstacles, the plan is arranged in the form of compiling the lesson plan, preparing the student observation sheet, teacher observation sheet, questionnaire, and prepare pre-test and post-test to be distributed to students, and also cards for learning in class using the Make a Match model. The basic competencies delivered are faith in qada and qadar. Learning is carried out in 1 meeting with an allocation of 2 hours.

2) Implementation of class I Actions

At this stage the first round of action will be held on Thursday 5 January 2017 1-2 hours (08.45-9.15). in this round the giver of action is the researcher himself while the recipient of the action is the students of class XII IPA 2 as many as 23 students. This learning process starts with opening greetings and tells students to read their prayers before starting the lesson, followed by student attendance and apperception of the material taught in the previous material. Next the teacher conveys the learning objectives, explains and explains the material about faith in qada and qadar, then the teacher invites students to ask questions, after completing equipping students with Faith material to qada and qadar the teacher explains about the Make a Match learning model that will be applied. Then the students are divided into 4 groups, each student gets one card and must look for pairs of answers / questions that are held until the game ends and students all get points. Next the teacher guides students to draw conclusions about the material they have learned. After the learning process is complete, the final test (post test) is given.

3) Observation, Final Test of Class Action I round

Learning in the classroom starts with an opening greeting, asks for the presence of students and asks students to prepare a book on Islamic Education. Students are given motivation about the importance of learning material faith in qada and qadar.

\section{Observation of Teacher Activities}

The results of the observations were carried out by two observers, namely Islamic Education subject teachers and colleagues who were tasked to observe researchers and

\footnotetext{
${ }^{1}$ KKM determination, minimum 70 
students as well during the learning process. To facilitate the observer, the researcher uses the observation guidelines given to the observer.

Table 4.3 Observation of Cycle I Teacher Activities

\begin{tabular}{|c|c|c|c|c|c|}
\hline No & Assessment Aspect & & ego & & \\
\hline A & Preparation & 1 & 2 & 3 & 4 \\
\hline 1 & $\begin{array}{l}\text { The teacher prepares the Learning } \\
\text { Implementation Plan }\end{array}$ & & & 3 & \\
\hline 2 & $\begin{array}{l}\text { Learning objectives are expressed in clear } \\
\text { sentences in lesson plans }\end{array}$ & & 2 & & \\
\hline 3 & $\begin{array}{l}\text { Learning material that will be given has a } \\
\text { connection or can be associated with } \\
\text { previous learning material }\end{array}$ & & 2 & & \\
\hline 4 & The teacher prepares learning media & & & 3 & \\
\hline 5 & $\begin{array}{l}\text { The teacher prepares class settings to } \\
\text { learn }\end{array}$ & & 2 & & \\
\hline 6 & The teacher prepares Student worksheets & & & 3 & \\
\hline 7 & Say greetings & & & 3 & \\
\hline 8 & Read the basmalah together & & 2 & & \\
\hline 9 & Students absent & & & 3 & \\
\hline 10 & Condition students & & & 3 & \\
\hline 11 & $\begin{array}{l}\text { The teacher prepares students physically } \\
\text { and mentally }\end{array}$ & & 2 & & \\
\hline 12 & $\begin{array}{l}\text { The teacher presents the learning } \\
\text { objectives to be achieved }\end{array}$ & & 2 & & \\
\hline 13 & The teacher explains the learning material & & & 3 & \\
\hline 14 & $\begin{array}{l}\text { During the learning process the teacher } \\
\text { gives students to ask questions }\end{array}$ & & 2 & & \\
\hline 15 & $\begin{array}{l}\text { When students ask the teacher gives a } \\
\text { clear and satisfying answer }\end{array}$ & & 2 & & \\
\hline 16 & Condition students & & 2 & & \\
\hline 17 & Divide students into 4 groups & & 2 & & \\
\hline 18 & The teacher distributes cards to students & & & 3 & \\
\hline 19 & $\begin{array}{l}\text { Every student gets a different card, a card } \\
\text { in the form of a question / answer }\end{array}$ & & 2 & & \\
\hline 20 & $\begin{array}{l}\text { Students match the answers to the cards } \\
\text { that have been obtained with their friends } \\
\text { repeatedly }\end{array}$ & & & 3 & \\
\hline 21 & $\begin{array}{l}\text { Students read aloud from a card that has } \\
\text { already been he got }\end{array}$ & & 2 & & \\
\hline 22 & $\begin{array}{l}\text { The teacher asks students about errors in } \\
\text { matching cards }\end{array}$ & 1 & & & \\
\hline 23 & Students return to their respective seats & & 2 & & \\
\hline 24 & $\begin{array}{l}\text { The teacher gives rigan punishment to } \\
\text { students who are wrong in matching cards }\end{array}$ & & 2 & & \\
\hline
\end{tabular}




\begin{tabular}{|l|l|l|l|l|l|}
\hline 25 & Exercises are given effectively & & & 3 & \\
\hline 26 & $\begin{array}{l}\text { Conclude the material learned with } \\
\text { students }\end{array}$ & & 2 & & \\
\hline 27 & $\begin{array}{l}\text { Give students the opportunity to ask } \\
\text { questions about material that is not yet } \\
\text { understood }\end{array}$ & & 2 & & \\
\hline 28 & Provide motivation to students & & & 3 & \\
\hline 29 & $\begin{array}{l}\text { Invite to read the do'a (hamdalah } \\
\text { together) }\end{array}$ & & 2 & & \\
\hline 30 & Ending the process of chasing by greeting & & 2 & & \\
\hline & \multicolumn{2}{|l|}{1} & 36 & 33 & 0 \\
\hline & total & 70 & & \\
\hline & Percentage & Category & \multicolumn{3}{|l|}{ Not good } \\
\hline
\end{tabular}

Data Source: Observer Data of Research Observation Results, 2017

Based on the data obtained in Table 4.8 above related to the activities of teachers in learning is still not good, the teacher has not done well every step in the lesson plan, according to the data from the teacher's observation at each meeting. In the first cycle the results obtained by the teacher reached $58 \%$ with information that was not good and did not meet $75 \%$.

The method for obtaining results on teacher activities is calculated through the following formula:

$$
\begin{aligned}
\text { Percentage of average }= & \begin{array}{l}
\mathrm{R} \\
-\mathrm{SM}
\end{array} \\
\text { Percentage of average }= & \frac{70}{120} \times 100 \% \\
= & 58 \%
\end{aligned}
$$

To be more clearly seen in the table and diagram below:

Table 4.4 Results of Observation of Cycle I Teacher Activities

\begin{tabular}{|l|l|}
\hline Stages & Teacher Activity \\
\hline Completeness of teaching activities & $58 \%$ \\
\hline total score & 70 \\
\hline
\end{tabular}

Data Source: Observer Data of Research Observation Results, 2017

Observation of Student Activities

Table 4.5 Observation of activities of students in cycle I

\begin{tabular}{|c|l|l|l|l|l|}
\hline No. & Assessment Aspect & \multicolumn{3}{|l|}{ Category } \\
\hline 1 & Answer greetings & & & 4 \\
\hline 2 & Answering teacher questions & & 3 & \\
\hline 3 & Listen to the teacher's explanation & & 3 & \\
\hline 4 & Pay attention to the teacher's explanation & 2 & & \\
\hline 5 & Submit opinions or answers to teacher questions & & 2 & & \\
\hline
\end{tabular}




\begin{tabular}{|l|l|l|l|l|}
\hline 6 & Asking things that are not clear & 2 & & \\
\hline 7 & Pay attention to the teacher's explanation & & 3 & \\
\hline 9 & Submit opinions or ask questions related to material & 2 & & \\
\hline 10 & $\begin{array}{l}\text { Answering teacher questions related to the } \\
\text { material }\end{array}$ & 2 & & \\
\hline 11 & Express opinions & 2 & & \\
\hline 12 & $\begin{array}{l}\text { Correcting errors or shortcomings in the learning } \\
\text { process }\end{array}$ & & 3 & \\
\hline 13 & $\begin{array}{l}\text { Listen to the teacher's explanation regarding the } \\
\text { implementation of the Make a Match model }\end{array}$ & 2 & & \\
\hline 14 & Follow the learning process in an orderly manner & 2 & & \\
\hline 15 & Comment and conclude the learning process & 2 & & \\
\hline 16 & Fill out / answer worksheets according to instructions & 2 & & \\
\hline 17 & Ask if something has not been understood & & 3 & \\
\hline 18 & $\begin{array}{l}\text { Gathering answers related to the post test given by the } \\
\text { teacher }\end{array}$ & & 3 & \\
\hline 19 & Students give conclusions together with the teacher & & 3 & \\
\hline 20 & Answer greetings & & 3 & \\
\hline & \multicolumn{2}{|l|}{20} & 24 & 4 \\
\hline & Total & 68 & & \\
\hline & Percentage & Not Good & \\
\hline & Category & & & \\
\hline
\end{tabular}

Data Source: Observer Data of Research Observation Results, 2017

Based on data from the table above, it is known that in student learning activities still show poor activity, note the value that shows the percentage reaches $60 \%$, but the value still needs to be increased for $75 \%$ completeness. This is because students are still doing other work that disrupts the learning process so that it does not concentrate on the material being studied. Yhe way to find out the results of student activities is calculated through the following formula:

$$
\begin{aligned}
\mathrm{Pk} & =\frac{\mathrm{S}}{\mathrm{SM}} \times 100 \% \\
\mathrm{Pk} & =\frac{48}{80} \times 100 \% \\
& =60 \%
\end{aligned}
$$

To be more clearly seen in the table and diagram below:

Table 4.6 Results of Observation of Student Activity in Cycle I

\begin{tabular}{|l|l|}
\hline Stages & Teacher Activity \\
\hline Completeness of student activity & $60 \%$ \\
\hline total score & 48 \\
\hline
\end{tabular}

Data Source: Observer Data of Research Observation Results, 2017 
Diagram 4.2 Activity Graph of Cycle I students

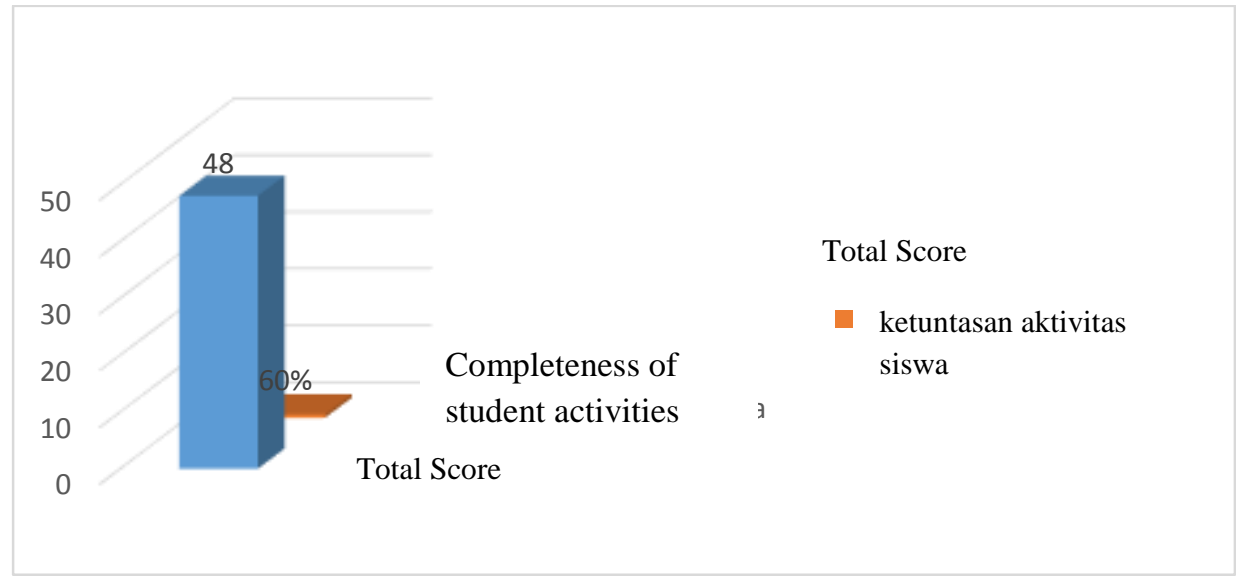

Data Source: Observer Data of Research Observation Results, 2017

Cycle I Final Test Results

Table 4.7 List of Value of Student Cycle I Learning Outcomes

\begin{tabular}{|l|l|l|c|c|}
\hline & Name & Value & Complete & Uncompleted \\
\hline 1 & Andi Erizal & 80 & $\checkmark$ & \\
\hline 2 & Ernawati & 50 & & $\checkmark$ \\
\hline 3 & Ghanda Arsenda & 75 & $\checkmark$ & \\
\hline 4 & Husna Wahyuni & 75 & $\checkmark$ & \\
\hline 5 & Ilham Amrin & 70 & $\checkmark$ & \\
\hline 6 & Isra Mianda & 60 & & $\checkmark$ \\
\hline 7 & Lisma Ismail & 75 & $\checkmark$ & \\
\hline 8 & Marhaban & 80 & $\checkmark$ & \\
\hline 9 & Mirna Lisa & 75 & $\checkmark$ & \\
\hline 10 & Nelva Amiriza & 65 & & $\checkmark$ \\
\hline 11 & Nova Rosita & 45 & & $\checkmark$ \\
\hline 12 & Nurgantisyah & 80 & $\checkmark$ & \\
\hline 13 & Nurjanah & 45 & & $\checkmark$ \\
\hline 14 & Nyak Baren & 75 & $\checkmark$ & \\
\hline 15 & Rahmawati & 80 & $\checkmark$ & \\
\hline 16 & Riski Juanda & 70 & $\checkmark$ & \\
\hline 17 & Riski Safriana & 75 & $\checkmark$ & \\
\hline 18 & Salmianti & 60 & & $\checkmark$ \\
\hline 19 & Ulva Ardianti & 60 & & $\checkmark$ \\
\hline 20 & Ulvia Rahmayanti & 60 & & $\checkmark$ \\
\hline 21 & Wawan Setiawan & 85 & $\checkmark$ & \\
\hline 22 & Yolanda & 50 & & $\checkmark$ \\
\hline 23 & Zulfikar & 1555 & 13 & 10 \\
\hline & Total & 67.60 & 56.52 & 43.47 \\
\hline & Average & 70 & & \\
\hline & Minimal completeness criteria & & \\
\hline $619 i n$ & Data Test Resuts for Researches, & & & \\
\hline
\end{tabular}

Obtain Data Test Results for Researchers, 2017 
As for knowing the value of student learning averages are calculated through the following formula:

$$
\begin{aligned}
\mathrm{M}_{\mathrm{x}} & =\frac{\Sigma X}{N} \\
& =\frac{1555}{23} \\
& =67.60
\end{aligned}
$$

For more details, we can see the tables and diagrams below:

Table 4.8 Student Cycle I Learning Outcomes

\begin{tabular}{|l|l|}
\hline Criteria & Cycle I \\
\hline $\begin{array}{l}\text { Average student learning } \\
\text { outcomes }\end{array}$ & 67.60 \\
\hline Student learning completeness & $56.52 \%$ \\
\hline
\end{tabular}

Data Source: Research Data Test Results for Researchers, 2017

Diagram 4.3 Graph of student learning outcomes in Cycle I

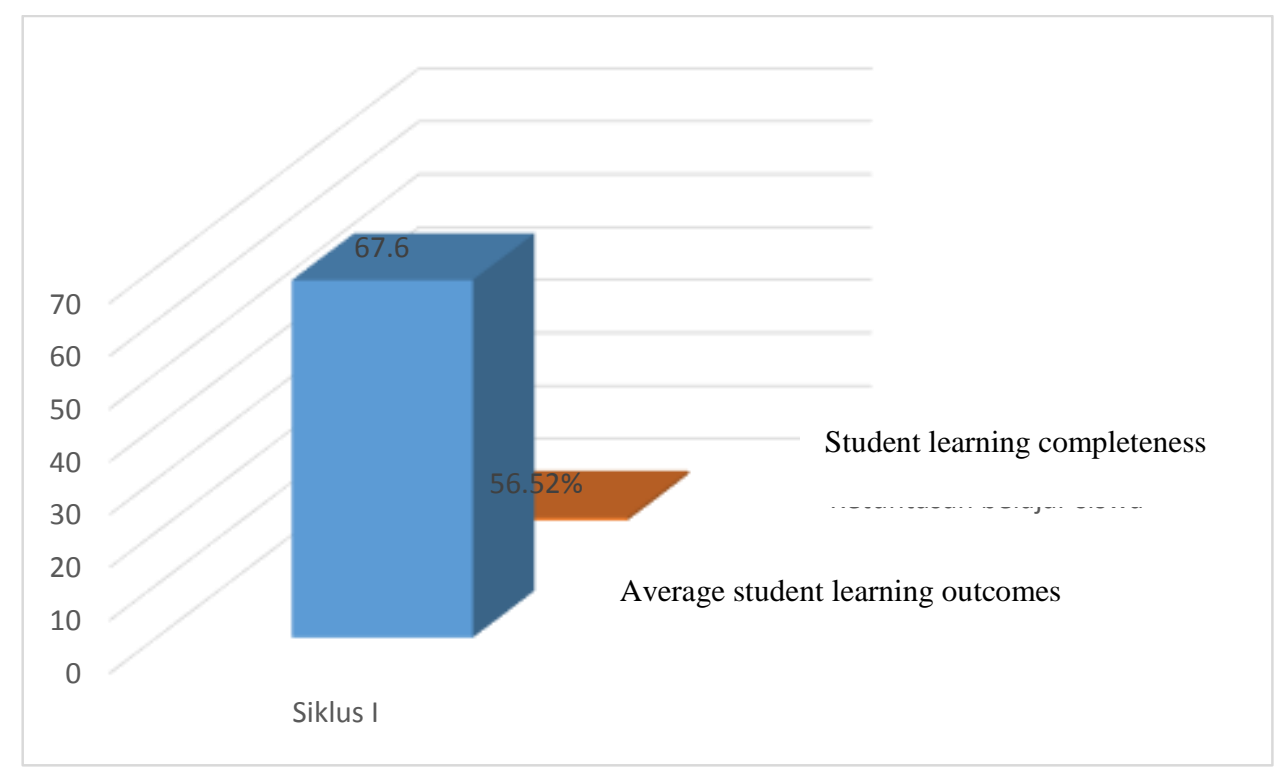

Data Source: Research Data Test Results for Researchers, 2017

Student Response

Table 4.9 Student Response Data cycle

\begin{tabular}{|l|l|l|l|l|l|}
\hline No & Statement & \multicolumn{4}{|l|}{ Alternative Answers } \\
\cline { 3 - 6 } & & SS & S & KS & TS \\
\hline 1 & $\begin{array}{l}\text { I feel satisfied with learning Make a } \\
\text { Match }\end{array}$ & 8.69 & 21.73 & 26.08 & 43.47 \\
\hline
\end{tabular}




\begin{tabular}{|c|c|c|c|c|c|}
\hline 2 & $\begin{array}{l}\text { The Make a Match model makes me } \\
\text { more active in learning }\end{array}$ & 4.34 & 30.43 & 34.78 & 30.43 \\
\hline 3 & $\begin{array}{l}\text { In learning Make a Match is my } \\
\text { motivation for learning is increasing }\end{array}$ & 13.04 & 17.39 & 30.43 & 39.13 \\
\hline 4 & $\begin{array}{l}\text { The Make a Match learning model } \\
\text { motivated me to study material about } \\
\text { marriage }\end{array}$ & 4,34 & 21.73 & 26.08 & 47.82 \\
\hline 5 & $\begin{array}{l}\text { Make a Match learning model can } \\
\text { eliminate boredom during the process of } \\
\text { teaching and learning activities }\end{array}$ & 8.69 & 17.39 & 26.08 & 47.82 \\
\hline 6 & $\begin{array}{l}\text { with the Make a Match model I often } \\
\text { collaborate with friends in learning }\end{array}$ & 17.39 & 17.39 & 34.78 & 30.43 \\
\hline 7 & $\begin{array}{l}\text { I agree the Make a Match learning } \\
\text { model is very suitable to be applied to } \\
\text { the subject matter of marriage material }\end{array}$ & 4.34 & 13.04 & 56.52 & 26.08 \\
\hline 8 & $\begin{array}{l}\text { Using the Make a Match learning model } \\
\text { makes me seriously study the subject } \\
\text { matter of Marriage }\end{array}$ & 4.34 & 8.69 & 60.86 & 26.08 \\
\hline 9 & $\begin{array}{l}\text { I agree the Make a Match learning } \\
\text { model is applied to other subject matter }\end{array}$ & 4.34 & 21.73 & 26.08 & 47.82 \\
\hline 10 & $\begin{array}{l}\text { The Make a Match learning model made } \\
\text { my curiosity great about the subject } \\
\text { matter of marriage }\end{array}$ & 13.04 & 4.34 & 65.21 & 17.39 \\
\hline 11 & $\begin{array}{l}\text { I feel that from the beginning of } \\
\text { learning, I have been interested in the } \\
\text { Make a Match learning model }\end{array}$ & 4.34 & 17.39 & 47.82 & 30.43 \\
\hline 12 & $\begin{array}{l}\text { I agree that the Make a Match learning } \\
\text { model is an effective and innovative } \\
\text { model }\end{array}$ & 13.04 & 17.39 & 30.43 & 39.13 \\
\hline 13 & $\begin{array}{l}\text { I feel more focused on learning with the } \\
\text { Make a Match model }\end{array}$ & 8.69 & 8.69 & 34.78 & 47.82 \\
\hline 14 & $\begin{array}{l}\text { I'm sure the Make a Match learning } \\
\text { model can improve my learning } \\
\text { outcomes }\end{array}$ & 4.34 & 8.69 & 60.86 & 26.08 \\
\hline 15 & $\begin{array}{l}\text { By using the Make a Match model I } \\
\text { love being able to learn while playing } \\
\text { and creating new things in learning on } \\
\text { wedding material }\end{array}$ & 4.34 & 21.73 & 43.47 & 30.43 \\
\hline 16 & $\begin{array}{l}\text { In learning Make a Match, each student } \\
\text { can participate and give judgment }\end{array}$ & 4.34 & 8.69 & 60.82 & 26.08 \\
\hline 17 & $\begin{array}{l}\text { In Make a Match learning, each student } \\
\text { can appreciate time by finding answers } \\
\text { to questions they have. }\end{array}$ & 13.04 & 8.69 & 43.47 & 34.78 \\
\hline 18 & $\begin{array}{l}\text { Learning using the Make a Match model } \\
\text { can increase my knowledge. }\end{array}$ & 4.34 & 56.52 & 30.43 & 8.69 \\
\hline
\end{tabular}




\begin{tabular}{|l|l|l|l|l|l|}
\hline & Total & 7.72 & 17.86 & 41.05 & 33.30 \\
\hline & & \multicolumn{3}{|c|}{$25.52 \%$} & $74.35 \%$ \\
\hline
\end{tabular}

Data Source: Obtain Data on Results of Student Response Questionnaire, 2017

For more details, see the table and diagram below:

Table 4.10 Results of Cycle I Student Response

\begin{tabular}{|l|l|}
\hline Stages & Student response \\
\hline Cycle I results & $25.52 \%$ \\
\hline Total Score & $100 \%$ \\
\hline
\end{tabular}

Data Source: Obtain Data on Results of Student Response Questionnaire, 2017

Diagram 4.4 Graph of Response of Cycle I students

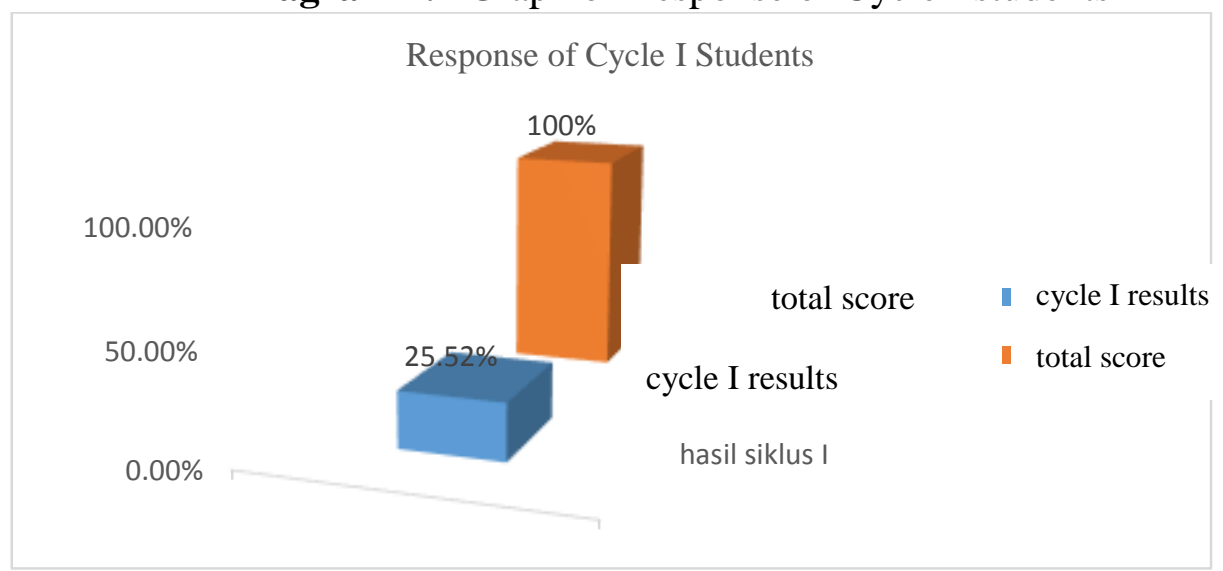

Data Source: Obtain Data on Results of Student Response Questionnaire, 2017

4). Reflection on class I round action

Based on the above data can be seen from the activities of the teacher and students, student learning outcomes and student responses to the Make a Match learning model, the overall value can be seen in the following diagram:

\section{Diagram 4.5: Overall Cycle I Diagram I}

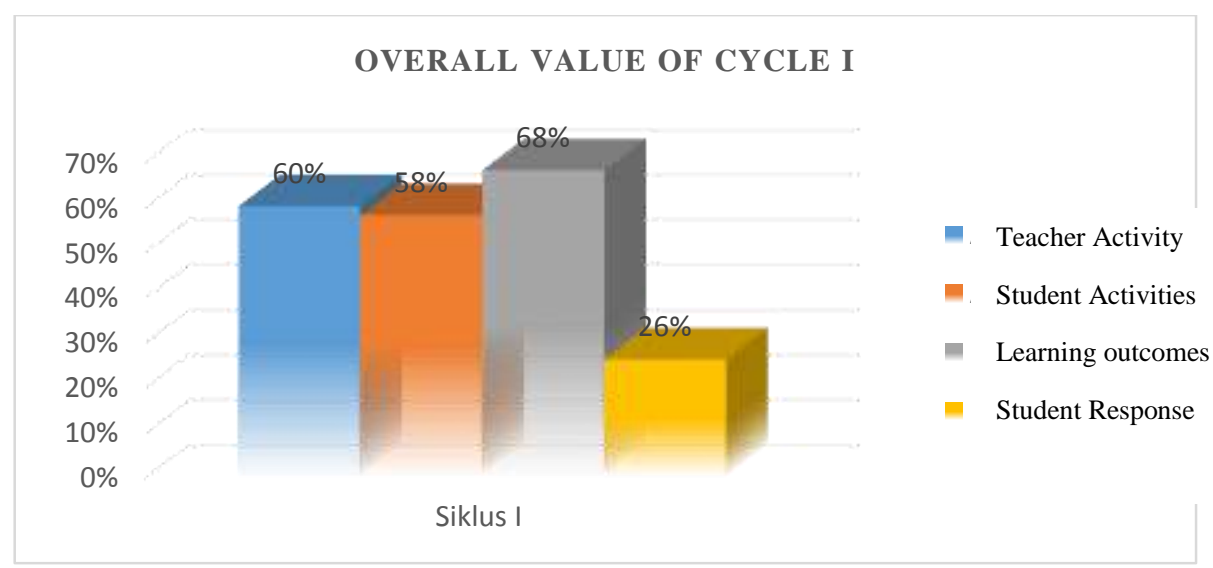

Source of Data: Outcome Data Results Value of overall Cycle I 
Table 4.11 Observation of teacher activity in cycle II

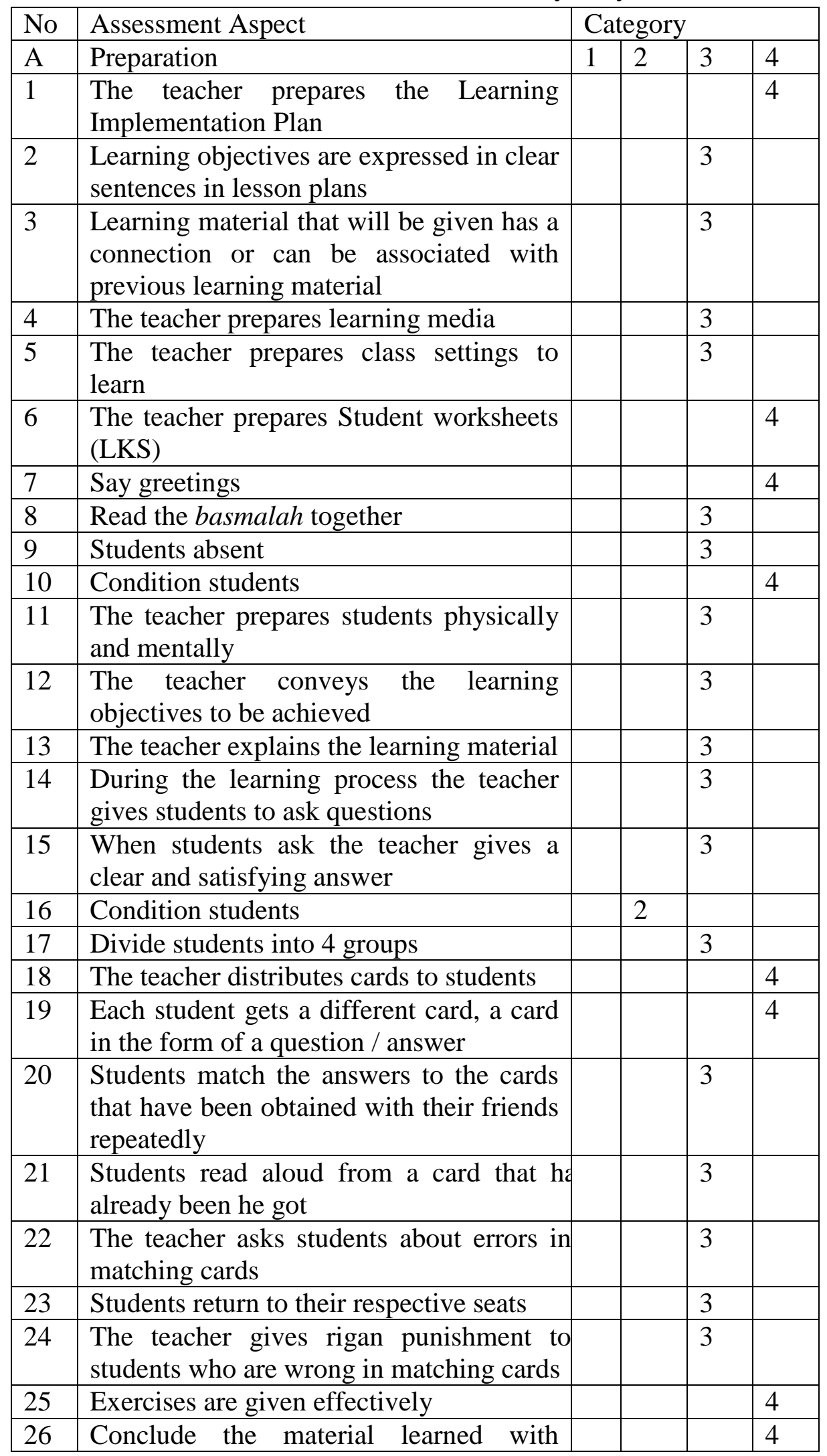




\begin{tabular}{|l|l|l|l|l|l|}
\hline 27 & students & & & & \\
\hline 28 & $\begin{array}{l}\text { Give students the opportunity to ask } \\
\text { questions about material that is not yet } \\
\text { understood }\end{array}$ & & & 3 & \\
\hline 29 & $\begin{array}{l}\text { Invite to read the do'a (hamdalah } \\
\text { together) }\end{array}$ & & & 3 & \\
\hline 30 & $\begin{array}{l}\text { Ending the learning process by saying } \\
\text { hello }\end{array}$ & & & & 4 \\
\hline & Total & 0 & 2 & 60 & 36 \\
\hline & Percentage & 98 & & \\
\hline Category & $81.66 \%$ & \\
\hline
\end{tabular}

Data Source: Observer Data of Research Observation Results, 2017

Thus the value obtained in the activity of teacher performance is calculated as follows:

$$
\begin{aligned}
\text { Presentase Nilai rata-rata } & =\frac{\mathrm{R}}{\mathrm{SM}} \times 100 \% \\
\text { Presentase Nilai rata-rata } & =\frac{98}{120} \times 100 \% \\
& =81.66 \%
\end{aligned}
$$

To be more clearly seen in the table and diagram below:

Table 4.12 Results of Observation of Cycle II Teacher Activities

\begin{tabular}{|l|l|}
\hline Stages & Teacher Activity \\
\hline Completeness of teaching activities & $81.66 \%$ \\
\hline Total Score & 98 \\
\hline
\end{tabular}

Data Source: Observer Data of Research Observation Results, 2017

Diagram 4.6 Graph of Teacher Cycle II Activity

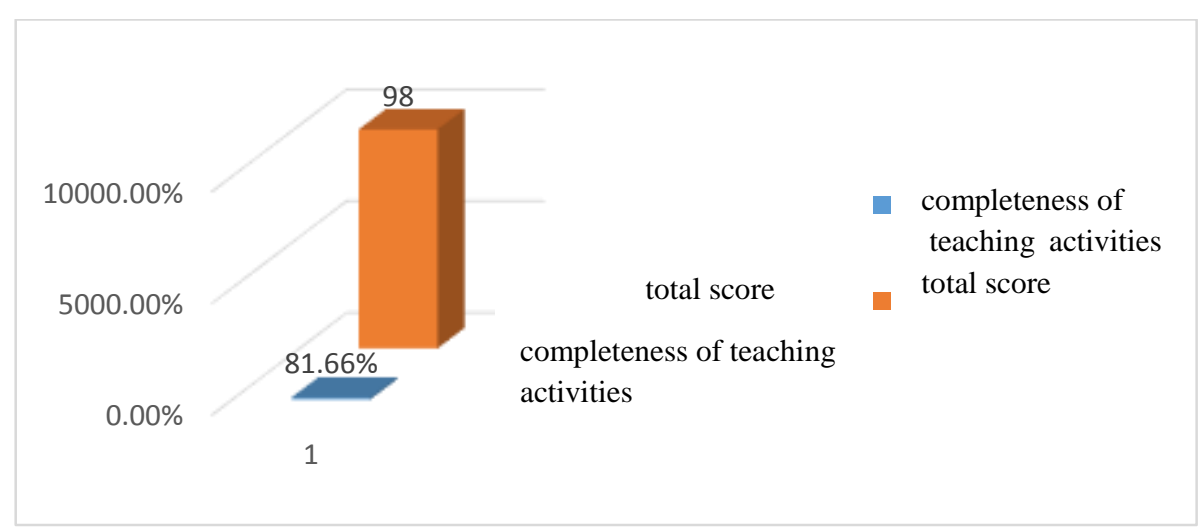

Data Source: Observer Data of Research Observation Results, 2017 
a. Observation of Student Activities

On the results of observations to assess student activities carried out by peers during the learning process from beginning to end. For things that are observed can be seen in the table below:

Table 4.13 Observation of cycle II student activities

\begin{tabular}{|c|c|c|c|c|}
\hline \multirow{2}{*}{\begin{tabular}{|c|} 
No \\
1 \\
\end{tabular}} & \multirow{2}{*}{$\begin{array}{l}\text { Assessment Aspect } \\
\text { Answer greetings }\end{array}$} & \multicolumn{3}{|c|}{ Category } \\
\hline & & & & 4 \\
\hline 2 & Answering teacher questions & & 3 & \\
\hline 3 & Listen to the teacher's explanation & & 3 & \\
\hline 4 & Pay attention to the teacher's explanation & & & 4 \\
\hline 5 & $\begin{array}{l}\text { Submit opinions or answers to teacher } \\
\text { questions }\end{array}$ & & 3 & \\
\hline 6 & Asking things that are not clear & & 3 & \\
\hline 7 & Pay attention to the teacher's explanation & & & 4 \\
\hline 9 & $\begin{array}{l}\text { Submit opinions or ask questions related to } \\
\text { material }\end{array}$ & & 3 & \\
\hline 10 & $\begin{array}{l}\text { Answering teacher questions related } \\
\text { to the material }\end{array}$ & & 3 & \\
\hline 11 & Express opinions & & 3 & \\
\hline 12 & $\begin{array}{l}\text { Correcting errors or shortcomings in the } \\
\text { learning process }\end{array}$ & & & 4 \\
\hline 13 & $\begin{array}{l}\text { Listen to the teacher's explanation } \\
\text { regarding the implementation of the Make } \\
\text { a Match model }\end{array}$ & & 3 & \\
\hline 14 & $\begin{array}{l}\text { Follow the learning process in an orderly } \\
\text { manner }\end{array}$ & & 3 & \\
\hline 15 & $\begin{array}{l}\text { Comment and conclude the learning } \\
\text { process }\end{array}$ & & 3 & \\
\hline 16 & $\begin{array}{l}\text { Fill out / answer worksheets according to } \\
\text { instructions }\end{array}$ & & 3 & \\
\hline 17 & Ask if something has not been understood & & & 4 \\
\hline 18 & $\begin{array}{l}\text { Gathering answers related to the post test } \\
\text { given by the teacher }\end{array}$ & & & 4 \\
\hline 19 & $\begin{array}{l}\text { Students give conclusions together with the } \\
\text { teacher }\end{array}$ & & & 4 \\
\hline 20 & Answer greetings & & & 4 \\
\hline & & 0 & 33 & 32 \\
\hline & Total & 65 & & \\
\hline & Percentage & $81.25 \%$ & & \\
\hline & Category & Very G & ood & \\
\hline
\end{tabular}

Data of Research Observation Results, 2016 
The way to find out the results of student activities is calculated through the following formula:

$$
\begin{aligned}
\mathrm{Pk} & =\frac{\mathrm{S}}{\mathrm{SM}} \times 100 \% \\
\mathrm{Pk} & =\frac{65}{80} \times 100 \% \\
& =81.25 \%
\end{aligned}
$$

To be more clearly seen in the table and diagram below:

Table 4.14 Results of Observation of Student Activity in Cycle I

\begin{tabular}{|l|l|}
\hline Stages & student activity \\
\hline Completeness of student activities & $81.25 \%$ \\
\hline total skor & 65 \\
\hline
\end{tabular}

Data Source: Observer Data of Research Observation Results, 2017

Diagram 4.7 Activity Chart of students in Cycle II

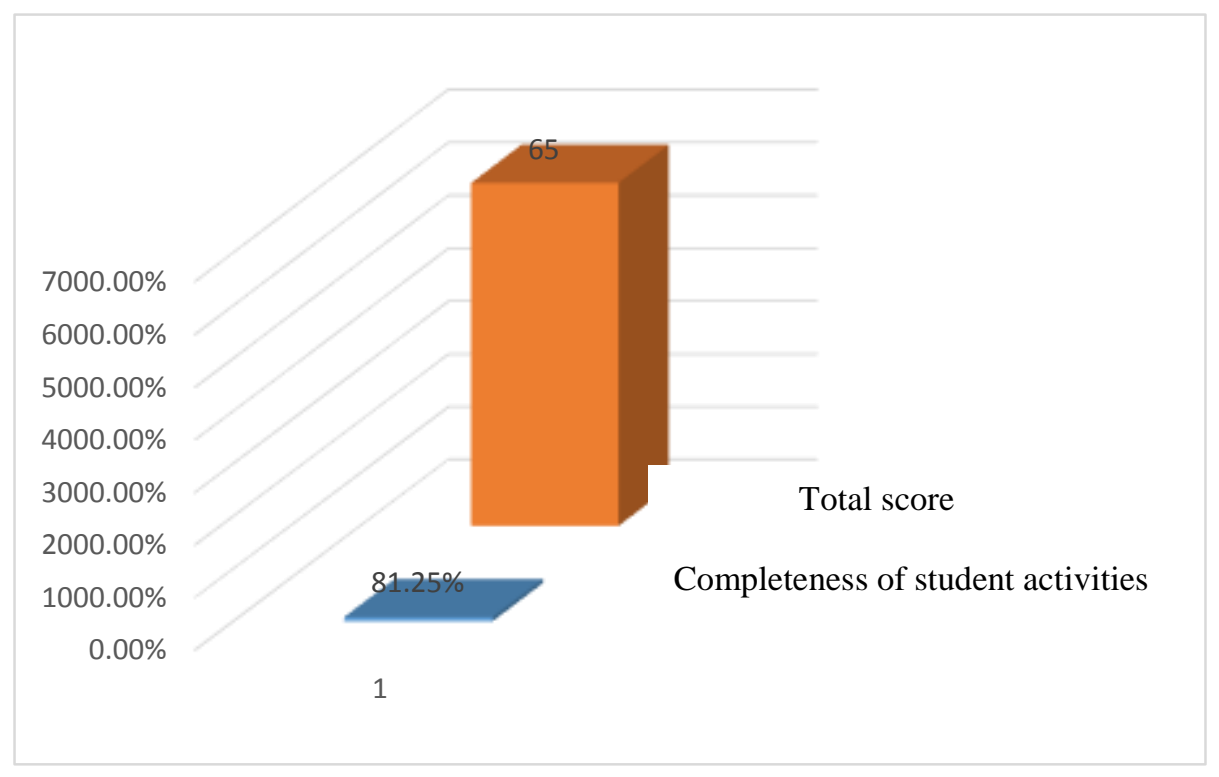

Data Source: Observer Data of Research Observation Results, 2017

b. Final cycle II test results

Table 4.15 List of Cycle II Learning Outcomes

\begin{tabular}{|l|l|l|c|c|}
\hline No & Name & Value & Complete & Uncompleted \\
\hline 1 & Andi Erizal & 80 & $\checkmark$ & \\
\hline
\end{tabular}




\begin{tabular}{|l|l|l|c|c|}
2 & Ernawati & 75 & $\checkmark$ & \\
\hline 3 & Ghanda Arsenda & 80 & $\checkmark$ & \\
\hline 4 & Husna Wahyuni & 85 & $\checkmark$ & \\
\hline 5 & Ilham Amrin & 75 & $\checkmark$ & \\
\hline 7 & Lisma Ismail & 80 & $\checkmark$ & \\
\hline 8 & Marhaban & 80 & $\checkmark$ & \\
\hline 9 & Mirna Lisa & 85 & $\checkmark$ & \\
\hline 10 & Nelva Amiriza & 80 & $\checkmark$ & \\
\hline 11 & Nova Rosita & 75 & $\checkmark$ & \\
\hline 12 & Nurgantisyah & 75 & $\checkmark$ & \\
\hline 13 & Nurjanah & 80 & $\checkmark$ & \\
\hline 14 & Nyak Baren & 60 & & $\checkmark$ \\
\hline 15 & Rahmawati & 85 & $\checkmark$ & \\
\hline 16 & Riski Juanda & 80 & $\checkmark$ & \\
\hline 17 & Riski Safriana & 75 & $\checkmark$ & \\
\hline 18 & Salmianti & 80 & $\checkmark$ & \\
\hline 19 & Ulva Ardianti & 85 & $\checkmark$ & \\
\hline 20 & Ulvia Rahmayanti & 65 & & $\checkmark$ \\
\hline 21 & Wawan Setiawan & 85 & $\checkmark$ & \\
\hline 22 & Yolanda & 65 & & \\
\hline 23 & Zulfikar & 85 & $\checkmark$ & \\
\hline & Total & 1790 & 20 & 3 \\
& Average & 77.82 & 86.95 & 13.04 \\
\hline & Minimal completeness criteria & & & \\
\hline Sata & Source: Data Obtaning Student $2 e a r i n g$ & \\
\hline
\end{tabular}

Data Source: Data Obtaining Student Learning Test Results, 2017

Based on the table above can be described as follows, out of 23 students as many as 20 students or $82 \%$ have completed or reached KKM. A total of 3 students or $18 \%$ have not yet completed or have not reached KKM. Average class 76.36.

As for knowing the value of student learning averages are calculated through the following formula:

$$
\begin{aligned}
\mathrm{M}_{\mathrm{x}} & =\frac{\Sigma X}{N} \\
& =\frac{1790}{23} \\
& =77.82
\end{aligned}
$$

For more details, see the Tables and Graphs below:

Table 4.16 Student Cycle II Learning Outcomes

\begin{tabular}{|l|l|}
\hline Criteria & Cycle I \\
\hline $\begin{array}{l}\text { Average student learning } \\
\text { outcomes }\end{array}$ & 78 \\
\hline Student learning completeness & $87 \%$ \\
\hline
\end{tabular}

Data Source: Data Obtaining Student Learning Test Results, 2017 
Diagram 4.8 Graphs of Student Cycle II Learning Outcomes

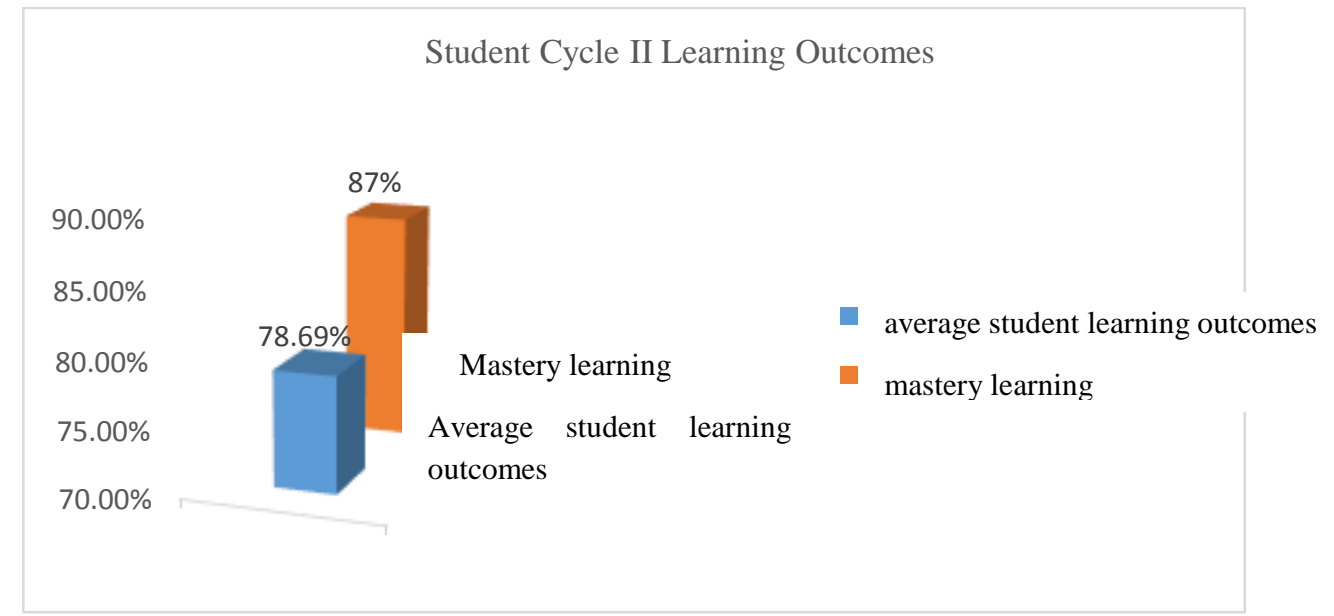

Data Source: Data Obtaining Student Learning Test Results, 2017

Thus it can be said that the Make a Match learning model is able to improve the learning completeness of class XII students of Pasie Raja 1 High School.

c. Student Response

Table 4.17 Student Response Data cycle II

\begin{tabular}{|l|l|l|l|l|l|}
\hline No & Statement & \multicolumn{3}{|l|}{ Alternative Answers } \\
\cline { 3 - 6 } & & SS & S & KS & TS \\
\hline 1 & $\begin{array}{l}\text { I feel satisfied with learning Make } \\
\text { a Match }\end{array}$ & 60.86 & 30.43 & 4.34 & 4.34 \\
\hline 2 & $\begin{array}{l}\text { The Make a Match model makes me } \\
\text { more active in learning }\end{array}$ & 34.78 & 52.17 & 8.69 & 4.34 \\
\hline 3 & $\begin{array}{l}\text { In learning Make a Match my } \\
\text { motivation for learning is increasing }\end{array}$ & 17.38 & 56.52 & 21.73 & 4.34 \\
\hline 4 & $\begin{array}{l}\text { The Make a Match learning model } \\
\text { motivated me to study material } \\
\text { about marriage }\end{array}$ & $\begin{array}{l}\text { eng.08 } \\
\text { eliminate boredom during the } \\
\text { process of teaching and learning } \\
\text { activities }\end{array}$ & 43.47 & 17.39 & 13.04 \\
\hline 6 & $\begin{array}{l}\text { with the Make a Match model I } \\
\text { often collaborate with friends in } \\
\text { learning }\end{array}$ & 17.39 & 21.73 & 47.82 & 13.04 \\
\hline 7 & $\begin{array}{l}\text { I agree the Make a Match learning } \\
\text { model is very suitable to be applied } \\
\text { to the subject matter of marriage } \\
\text { material }\end{array}$ & 43.47 & 34.78 & 13.04 & 8.69 \\
\hline
\end{tabular}




\begin{tabular}{|c|c|c|c|c|c|}
\hline 8 & $\begin{array}{l}\text { Using the Make a Match learning } \\
\text { model makes me seriously study the } \\
\text { subject matter of Marriage }\end{array}$ & 47.82 & 43.47 & 4.34 & 4.34 \\
\hline 9 & $\begin{array}{l}\text { I agree the Make a Match learning } \\
\text { model is applied to other subject } \\
\text { matter }\end{array}$ & 20.43 & 52.17 & 13.04 & 4.13 \\
\hline 10 & $\begin{array}{l}\text { The Make a Match learning model } \\
\text { made my curiosity great about the } \\
\text { subject matter of marriage }\end{array}$ & 26.08 & 69.56 & 4.34 & 0 \\
\hline 11 & $\begin{array}{l}\text { I feel that from the beginning of } \\
\text { learning, I have been interested in } \\
\text { the Make a Match learning model }\end{array}$ & 34.78 & 52.17 & 4.34 & 8.69 \\
\hline 12 & $\begin{array}{l}\text { I agree that the Make a Match } \\
\text { learning model is an effective and } \\
\text { innovative model }\end{array}$ & 21.73 & 69.56 & 4.34 & 4.34 \\
\hline 13 & $\begin{array}{l}\text { I feel more focused on learning } \\
\text { with the Make a Match model }\end{array}$ & 21.73 & 60.86 & 13.04 & 4.34 \\
\hline 14 & $\begin{array}{l}\text { I'm sure the Make a Match learning } \\
\text { model can improve my learning } \\
\text { outcomes }\end{array}$ & 17.39 & 69.56 & 4.34 & 8.69 \\
\hline 15 & $\begin{array}{l}\text { By using the Make a Match model I } \\
\text { love being able to learn while } \\
\text { playing and creating new things in } \\
\text { learning on wedding material }\end{array}$ & 21.73 & 65.21 & 8.69 & 4.34 \\
\hline 16 & $\begin{array}{l}\text { In learning Make a Match, each } \\
\text { student can participate and give } \\
\text { judgment }\end{array}$ & 17.39 & 69.56 & 4.34 & 8.69 \\
\hline 17 & $\begin{array}{l}\text { In Make a Match learning, each } \\
\text { student can appreciate time by } \\
\text { finding answers to questions they } \\
\text { have. }\end{array}$ & 43.47 & 47.82 & 4.34 & 4.34 \\
\hline 18 & $\begin{array}{l}\text { Learning using the Make a Match } \\
\text { model can increase my knowledge. }\end{array}$ & 30.43 & 56.52 & 8.69 & 4.34 \\
\hline & Total & 29.17 & 52.16 & 11.10 & 6.02 \\
\hline & Average & \multicolumn{2}{|c|}{$81.33 \%$} & \multicolumn{2}{|c|}{$17.12 \%$} \\
\hline
\end{tabular}

Data Source: Obtain Data on Results of Student Response Questionnaire, 2017

Based on the table above, it can be seen that out of 23 students / respondents obtained a percentage of different answers to each questionnaire statement. Examples based on table 4.18 can be seen from the results of statements on the Make a Match learning model. It can be said that 23 students said that they agreed that learning using the Make a Match model could improve learning outcomes and activity in the teaching and learning process.

For more details, see the Tables and Graphs below: 
Table 4.18 Results of Student Response Cycle II

\begin{tabular}{|l|l|}
\hline Stages & Student response \\
\hline The results of the first cycle & $81.33 \%$ \\
\hline total score & $100 \%$ \\
\hline
\end{tabular}

Data Source: Obtain Data on Results of Student Response Questionnaire, 2017

Diagram 4.9 Response Graph of Cycle II students

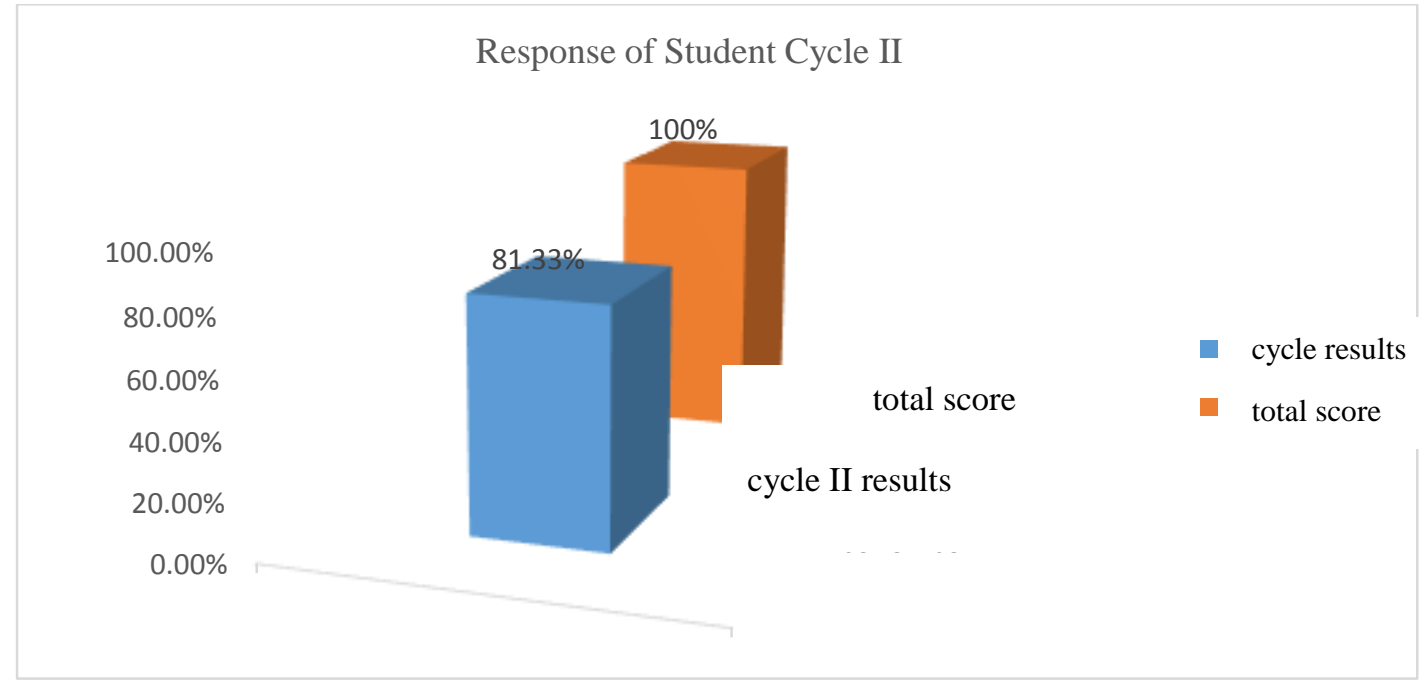

Data Source: Obtain Data on Results of Student Response Questionnaire, 2017

d. Reflection on Round II Class Actions

The results of observations made in the second cycle show that students are more active, enthusiastic, and serious in participating in learning activities. The implementation of the second cycle looks better than the first cycle, this is evidenced by the increasing evaluation results at the end of the second cycle. To find out more clearly the increase in results in cycle II can be seen in the following diagram:

Diagram 4.10. Graph of the overall value of Cycle II

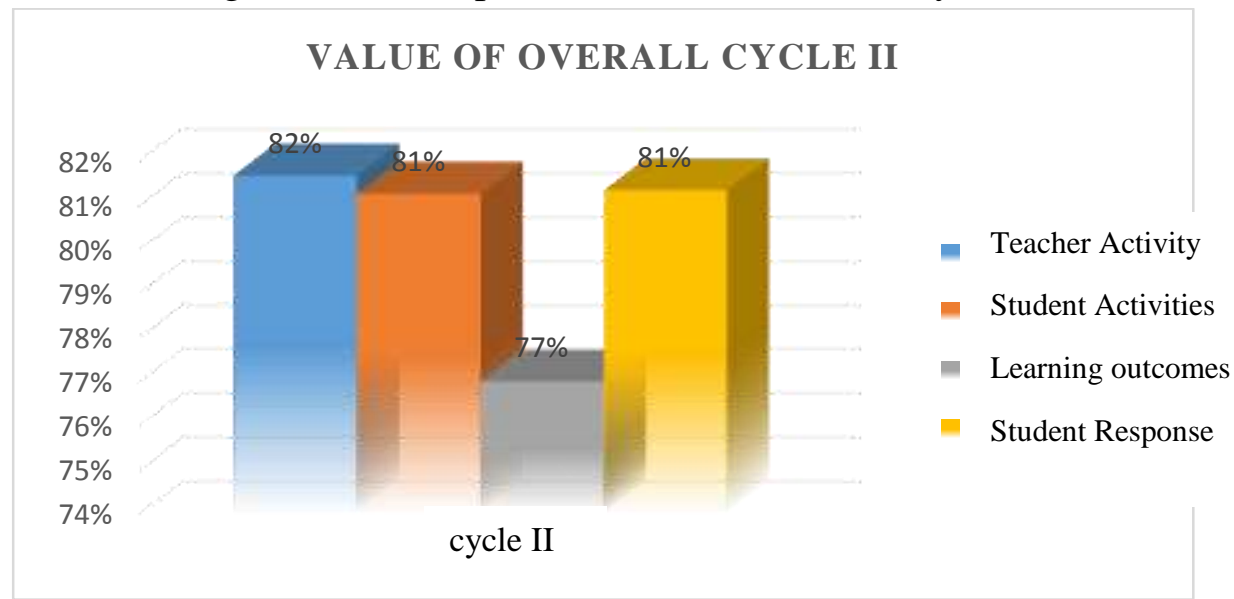

Data Source: Obtain Data on the Overall Value of Cycle II 
From the data above shows the average value of the class in the second cycle is 77.82 greater than the first cycle which is only 67.60 and also the percentage of student learning completeness is $78 \%$ greater than the first cycle which is only $68 \%$, this can be seen from the results of each value students experience completeness in accordance with the determined KKM which is 70. Likewise with the results of the value of student responses to the Make a Match model has been very positive reaching $81 \%$ better than the first cycle which is only $26 \%$. So the research conducted in the second cycle experienced success.

\section{Conclusion}

After conducting research, by applying the Make a Match learning model the results were obtained, there was an increase in student learning outcomes. The actions taken by Islamic Education teachers are Make a Match learning models. The aim is to create learning that is able to attract students' attention, provide knowledge to students to work together with other students in terms of understanding material, able to make students active and enthusiastic in learning. In addition, it can also make students able to reach the Minimal completeness criteria graduation limit. The comparison between learning outcomes before taking action and after taking action reached 39.69\%. Where the initial results before taking action are $39 \%$ but after taking action the student learning outcomes reach $78 \%$.

\section{References}

Ana Sudijono, Pengantar Statistik Pendidikan, Jakarta : PT Raja Grafindo Persada, 2010.

Anzar, S.F. and Mardhatillah, M. Analisis Kesulitan Belajar Siswa Pada Pembelajaran Bahasa Indonesiadi Kelas V SD Negeri 20 Meulaboh Kabupaten Aceh Barat Tahun Ajaran 2015/2016. Bina Gogik, 4(1). 2018.

Burhan Bungin, Metodologi Penelitian Kuantitatif, Jakarta : Kencana, 2011.

Departemen Agama RI, Al-qur'an dan terjemahannya, Bogor: Sygma Examedia Arkanleema, 2007.

Hamzah B. Uno, Menjadi Peneliti PTK yang Profesional, Jakarta : Bumi Aksara, 2012.

Depdikbud, Kamus Besar Bahasa Indonesia, Jakarta: Balai Pustaka, 2005.

Kunandar, Langkah Mudah Penelitian Tindakan Kelas Sebagai Pengembangan Profesi Guru, Jakarta: Rajawali pers, 2011.

Mardhatillah, M., \& Trisdania, E. Pengembangan Media Pembelajaran Berbasis Macromedia Flash Untuk Meningkatkan Kemampuan Membaca Siwa di SD Kelas II Negeri Paya Peunaga Kecamatan Meureubo. Bina Gogik. 5(1). 2018

Muhammad Thobroni and Arif Mustofa, Belajar dan Pembelajaran Pengembangan Wacana dan Praktik Pembelajaran dalam pembangunan Nasional, Jogjakarta: Ar-Ruzz Media, 2013.

Medi Yanto, jadi guru yang jago penelitian tindakan kelas, Yogyakarta: CV Andi Offset, 2013.

Nana Ibrahim, R., Syaodih S, Perencanaan Pengajaran. Jakarta: Rineka Cipta. 2010.

Rusman, Model-Model Pembelajaran, Jakarta: Rajawali Pers, 2011.

Ruswandi,Psikologi Pembelajaran,Jakarta: CV. Cipta Pesona Sejahtera, 2013 
Setyawan Pujiono, article. "Desain Penelitian Tindakan Kelas dan Teknik Pengembangan Kajian Pustaka, Yogyakarta: Universitas Negeri Yogyakarta, 2008.

Suharsimi Arikunto, Penelitian Tindakan Kelas, Jakarta: PT Bumi Aksara, 2009.

Slameto, Belajar dan Faktor yang Mempengaruhinya, Jakarta: Rineka Cipta,2009.

Sumadi Suryabrata, Metodologi Penelitian, (Jakarta: PT Raja grafindo Persada, 2011.

Syaiful Bahri Djamarah, Strategi Belajar Mengajar,Jakarta: Rineka Cipta,2013.

Syamsuri, Pendidikan Agama Islam SMA Jilid 3 untuk kelas XII,Jakarta: PT gelora Aksara Pratama, 2007

Tim Pengembang MKDP,Kurikulum dan Pembelajaran,Jakarta: Rajawali Pers, 2011

Trianto, Model Pembelajaran Terpadu, Jakarta: Bumi Aksara,2012.

Trianto, Mendesain Model Pembelajaran Inovatif-Progresif, (Jakarta: Kencana, 2011

Willis S sofyan, Psikologi Pendidikan, Bandung, Alfabeta, 2013

Wirdaningsih, W. and Mardhatillah, M. Penerapan Media Audio Visual Terhadap Keaktifan Pada Materi Hubungan Antara Sumber Daya Alam Dengan Lingkungan Siswa Kela VI SD Negeri Pasi Teungoh Kecamatan Kaway XVI. Bina Gogik, 3(2). 2016

W. S. Winkkel, Psikologi Pengajaran, Jakarta: Grasindo, 2008.

Novideswira,http://.blogspot.co.id/2013/07/pembelajaran-kooperatif-tipe-make-and_30.html. Accessed on 15 November 2011

Banisalam, http://.blogspot.co.id/2012/09/peningkatan-aktivitas-dan-hasil-belajar.html 